\title{
Introduction: Repositioning Feminisms in Gender and Development
}

\section{Andrea Cornwall, Elizabeth Harrison and Ann Whitehead*}

\section{Introduction}

This IDS Bulletin reflects on the contested relationship between feminism and development, and the challenges for reasserting feminist engagement with development as a political project. It arises from a workshop held at the Institute of Development Studies and the University of Sussex in July 2003. ${ }^{1}$ Centred on how to "reposition" gender and development, the workshop debates pointed to the politics of discourse as a key element in social transformation. Participants explored how, after initial struggles to develop new concepts and languages for understanding women's position in developing societies, feminist phrases came to be filled with new meanings as they were taken up into development policy and practice. Discussions turned on the ambiguous fruits of these struggles and their implications for feminist engagement with development.

One of the most foundational of these concepts, "gender", has served both as an organising principle and a rallying call. Researchers have used it to generate insights into the relational dimensions of planned intervention that development policy and practice had ignored. Activists and advocates have used it to frame a set of demands and to challenge, and reframe, assumptions. Lessons learnt from particular places have been turned into sloganised generalities: 'women are the poorest of the poor', 'women do most of the work in African agriculture', 'educating girls leads to economic development' ... and so on. Some have been used as Trojan Horses to open up debates and advocate positions. Others have become popular preconceptions, useful as a kind of catchy shorthand to capture the policy limelight. Others take the shape of feminist fables, cautionary tales told with educative intent. And still others gain the status of myths, stories whose potency rests in their resonance with deep-rooted convictions (cf. Sorel 1941). ${ }^{2}$ Women appear in these representations as abject ${ }^{3}$ victims, the passive subject of development's rescue, and splendid heroines, whose unsung virtues and whose contributions to development need to be heeded.

In many ways, the generalisations that are now part of the currency of gender and development represent a success story. Originating in the discourses of a minority of politically motivated advocates for gender change, they are now taken for granted and espoused by people occupying many different spaces in a multitude of development institutions. But the extent of change in women's lives does not match this discursive landslide. For many gender and development advocates, it appears that the more women and poverty are equated in development discourse, the more many women experience entrenched poverty; the more gender is mainstreamed, the less we find effective gender equality policies within key policy spaces and documents. Represented to technocrats and policymakers in the form of tools, frameworks and mechanisms, "gender" appears as neutralised of political intent. Diluted, denatured, depoliticised, included everywhere as an afterthought, "gender" has become something everyone knows that they are supposed to do something about. One bureaucrat summed it up: "when it comes to "gender", everyone sighs'.

There has been no shortage of reflexive engagement within gender and development research, writing and activism (Kabeer 1994; Goetz 1997; Miller and Razavi 1998). The collection edited by Cecile Jackson and Ruth Pearson (1998), Feminist Visions of Development, critically reflected on changing orthodoxies, and on issues of positionality and representation. A growing and increasingly sophisticated literature exists on the experience of gender mainstreaming (for example, Macdonald 
2003; Rai 2003; Kabeer 2003). Our aim in convening the workshop on which this IDS Bulletin was based was to engage with these debates through a particular lens, that of the narratives that gender and development had done much to popularise. This introduction draws on workshop debates to situate the articles in this collection in broader perspective. $^{4}$

\section{Perspectives and positions}

Gender and development (GAD) now embraces a significant body of practitioners, activists, donors and academics. The workshop sought to identify and bring together a diversity of voices and perspectives from across this field. We invited researchers and practitioners who had been involved with key conceptual and political advances in analysis and policy to reflect on how their own work had been transformed as gender equality and gender justice issues had been successfully placed on the development agenda. We also invited a number of gender "champions" from development organisations, and researchers and practitioners engaged in critical reflection on gender generalisations and their implications for policy and practice. Together, we sought to interrogate and understand how and with what consequences particular ideas about gender had come to be taken up by mainstream development organisations.

Reflecting years of effort to achieve gender justice and get new ways of working taken on by development agencies, the articles in this IDS Bulletin advance different critiques of how gender has been understood and policies implemented, different understandings of the way in which institutions influence outcomes, as well as different views of the pitfalls and compromises of political engagement. One widely shared initial perspective, however, was a sobering recognition of the enormous gap between feminists' aspirations for social transformation and the limited, though important, gains that have been made. Gender inequality has proved to be much more intractable, and resistance in bureaucracies to be much more sustained, than anticipated. Many participants shared a sense of disillusionment with what had become of "gender" in development, and a feeling of frustration with essentialisms and generalisations, simplifying frameworks and simplistic slogans.

Our discussions revealed layers of contestation around what both "gender" and "development" meant to us - and what they could mean for us. However, rather than becoming, as some feared, an exercise in deconstructing the achievements of GAD, the workshop helped reposition successes and sharpen our reflection on issues of strategy and direction. In so doing, it captured a shared concern with repoliticising the project of feminist engagement with development and gave many of us a sense of renewed energy and commitment.

The IDS Bulletin is structured as follows. Articles in Part I explore the origins and status of some of the gender orthodoxies that have become embedded in gender and development advocacy and programming. Some interrogate particular axioms, locating them within struggles for interpretative power that shape policy processes and politics. Others explore how policy fields have been constructed in specific ways in particular places. Part II turns to focus more directly on development institutions. Contributors examine the ways in which changing constructions of "gender" have framed the objects of development and set the parameters for debate and intervention. Speaking from different locations, contributors analyse the institutional dimensions of efforts at gender transformation. Several look closely at how gender mainstreaming has affected progress towards gender quality and the power of the gender agenda within development institutions.

The original workshop rationale focused on the myths and fables that emerge when research gets taken up into development. We were less reflexive, at that stage, about our own investments in certain ways of thinking about gender. From this vantage point, the kind of pervasive notions that we called "gender myths" were part of the problem, rather than - as we came to recognise - ideas that sometimes we ourselves hold dear, that help give us a sense of direction in our work, and that serve to represent our convictions as feminists engaging with development. We reflected on the mobilising power of a good myth, the usefulness of certain stories as ways to galvanise and inspire (cf. Hirschmann 1967). A key lesson that emerged from the workshop was that our discursive struggles over myths, fables and feminist "truths" had been part of the political process of engagement with the institutions, resources and discourses that make up development.

Locating "older" debates about women's rights, empowerment and material disadvantage on a new political canvas inscribed with concerns about 
rights, citizenship and the politics of inclusion, workshop discussions moved between situated practice and strategic positioning. This is reflected in Part III, which repositions the feminist engagement with development on a broader geopolitical terrain, capturing some of the struggles and conquests, as well as the new ambivalences and uncertainties, of today's international feminism. This section takes the form of shorter comment pieces, reflecting some of the more informal panel presentations of the workshop.

\section{A contested engagement with policy}

Feminists work towards social transformation and in doing so create new political spaces. The influence of forums such as DAWN (Development Alternatives with Women for a New Era) and AWID (Association for Women's Rights in Development), and the many international networks of researchers and activists, was much in evidence at the workshop; contributions provide several examples of critical struggles for voice, representation and resources through these forms of organisation and political space. The project of social transformation also demands engagement with the content and processes of development policy - not least because, despite the failure of most states to meet the target of 0.7 per cent of Gross Domestic Product for their aid budgets, spending in aid and loans has been rising in the last 25 years, and for many very poor countries this now constitutes a major source of government revenue.

In engaging with policy, many feminists have sought to make a place for new ideas and objectives in institutions whose organisation, resource distribution, cultures and power relations are not of their own making. Many of the articles in this IDS Bulletin reflect on the complex processes of making policy and provide highly nuanced accounts of becoming a player at these powerful tables. Running through them is a consciousness of the contradictions involved in seeking to bring about radical social change by engaging with those who hold the power and resources in international and national arenas. This point is raised explicitly by Islah Jad, who explores the multilateral agencies' support for Arab women's non-governmental organisations (NGOs) within the context of the USand UK-backed war of words, weapons and resources unleashed against particular Arab nations.
This support can be seen as part of a broader project of support to "bottom up" democracy, but is also possibly symptomatic of increasing dependency on the West. Islah accepts that the proliferating Arab women's NGOs may have a role to play: in advocating Arab rights in the international arena, providing services for certain groups, and developing policy and information bases. However, she also cautions against expectations that this will necessarily result in significant or deeply rooted changes in social structures.

Feminists engaging with development in different parts of the world have very different experiences, which come from the ways in which their nations and regions are positioned, materially, politically and discursively. In a powerful indictment of the development industry, Everjoice Win shows how difficult it is to exercise agency as an educated African feminist working as a policy advocate when the only African woman portrayed as having legitimate "voice" is a grassroots woman who is perpetually poor, powerless and pregnant. Everjoice's message is softened with humour but, together with that from Amina Mama, these are powerful accounts. They reveal the alienating and limited social, political and research identities available to African women in a world dominated by development institutions and development discourses. Feeling fawned upon by the ways in which development actors and initiatives want them, and ignored because they are seen through distorting and rigid stereotypes, these accounts remind us of the continuing importance of geopolitical position. Other articles reflect on the tensions between representations of women and preferred policy narratives. Nazneen Kanji and Carin Vijfhuizen show how difficult it is to voice policy messages from research in national contexts where the poverty agenda is so hegemonic. Similarly highlighting the disjunction between research findings and policy prerogatives, Sylvia Chant charts the disjunction between what is known about female-headed households and how they appear as targets in poverty policy.

While these articles hold policy at arm's length, several give detailed accounts of more intimate engagement with development institutions. The workshop participants included several who reflected on their work within powerful international agencies, for example within bilateral donors or UN organisations that interface with 
multilateral donors. Rosalind Eyben's description of how she strategised as a public sector bureaucrat to get gender onto the agenda, emphasises how the view from outside can all too easily miss the subtleties of the policy process. Rosalind's article vividly suggests the importance of the regular battles that feminists have to wage over particular policy outputs, whether these are publicity booklets, policy statements, or ministerial speeches. A different kind of process and engagement was described by Diane Elson during the workshop. Reflecting on the way in which feminist economists had succeeded in inserting gender within at least some streams of economic analysis, she argued that it had been important to seize upon the way in which economics as a discipline uses stylised facts and to provide appropriately gendered ones to make alliances with more progressive and radical economists.

The politics of institutional location - of what kind of institutions one is working in or for - is a theme that runs through many articles. Hilary Standing's article takes this as one of its main themes, and argues for the need to understand the mandates of different kinds of development institutions and actors in order to assess whether they should be held responsible for the social transformatory goals of feminism. She points out that the policy objectives of Government Ministries are centred on the services they are charged with delivering, such as health and education. Hilary's article is an account of the perils of de-contextualised and top-down gender mainstreaming (a theme returned to below). She poses a clear question: why do we expect sectoral ministries to be the site of the policy objectives of gender transformation? She suggests that many feminists have remained naive about the nature of policy processes and institutional change. Certainly, a more linear approach to policy-making has tended to inform explicit attempts to change policies. Yet there is also a broad recognition, as Anne Marie Goetz (1997) has pointed out, that what policy-makers and bureaucrats want to know will make for very selective uptake of insights produced by feminist researchers or lobbied for by feminist advocates.

\section{Technical solutions to political problems?}

Several of the articles in this IDS Bulletin, like the workshop discussions, are preoccupied by the question posed by Cecilia Sardenberg: how did "doing gender" become something different to "doing feminism"? One recurring theme is that of the ways in which the political project of gender and development has been reduced to a "technical" fix: as Maitrayee Mukhopadhyay puts it, something that is ahistorical, apolitical and decontextualised and 'which leaves the prevailing and unequal power relations intact'. But how did the essentially political - and at the same time, deeply personal - issues of gender get rendered technical in ways that narrow, rather than widen, the scope for transformation?

In Hilary Standing's account, the slippage occurs when donors take a top-down approach to their partners and insist on gender mainstreaming, gender training and gender goals as part of the establishment of externally demanded gender commitments and gender credentials. Hilary argues that gender interventions associated with externally imposed mainstreaming have become a stick with which to beat government bureaucrats. Another consequence of donor-national government relations is that country bureaucracies are working within a very tight space in which the policy objectives, the methods of arriving at them, and the forms of their delivery are externally driven as the Poverty Assessments and Poverty Reduction Strategies graphically illustrate. ${ }^{5}$

Where "gender" comes to be represented in the guise of approaches, tools, frameworks and mechanisms, these instruments become a substitute for deep changes in objectives and outcomes. The fit between the worlds they describe and any actually existing relationships between women and men is often partial. This emerges in Prudence WoodfordBerger's powerful account of the ways in which particular readings of "gender" come to form part of the gender recipes of donor agencies, no matter how little their Eurocentric ingredients fit with the realities of women's and men's lived experiences and relationships in other cultural contexts.

The professionalisation of gender and development has, several participants argued, become another technical fix, with an ever looser link with feminism. As Everjoice Win said at the workshop:

In some cases, mainstreaming is almost counterposed against feminism ... In some cases, young people come into this work not having been part of feminist analysis, thinking, groups etc., they come into this work largely as technocrats. They may be given the task of 
"mainstreaming gender", yet have not come from the feminist movement and have never engaged with the politics of these issues. In this case, you don't have the tools and analytical understanding that gender has come from feminism, and you are told constantly that the organisation is not a feminist organisation, but a development organisation, and mainstreaming is seen as an end in itself, not political.

Several commentators reflected that while professionalisation did loosen links with feminism, it has also provided livelihoods, work, and indeed identities, for feminists. The need to resource progressive work and projects requires some acceptance of the objectives and framings of those that hold the purse strings. Yet equally, it is still possible to find ways to work with gender in ways that are congruent with transformational agendas. The articles giving detailed accounts of how feminists have worked in different institutional sites contain some pointers as to how this can be done. Maitrayee Mukhopadhyay and Ramya Subrahmanian describe the disjunctures and dissonances that have accompanied the mainstreaming agenda as it has taken shape in several settings. Maitrayeee asks how possible it is to enforce gender equity commitments if institutions don't have the promotion of gender rights or gender justice as their objective. Drawing on the instructive example of gender in education policy in Australia, Ramya argues that it is necessary to get things right in many different political arenas to create the kind of synergy that will enable feminists working within government bureaucracies to be successful.

Turning the question of the efficacy of gender advocacy without supportive politics on its head, Jo Beall and Alison Todes argue that explicit gender commitments may have less to offer in processes of change than the advocates of tools such as "gender planning" might have us believe. In their case, the fact that women in Cato Manor in South Africa had a long and active history in community politics was the main factor in ensuring gender equity was advanced. Without this, a technical project of gender mainstreaming alone would have made little difference. Their analysis highlights the critical, and often overlooked, significance of contextual pre-conditions for transformatory gender practice.

To return to the vexed question of the "technical", it is clear that the meaning of gender remains contested, and becomes a particular object of contestation when it is applied and advocated within bureaucracies. Working within them, feminists are constantly frustrated when they come up against barriers to any exercise of power. The links that can be made with other feminists, locally, nationally and internationally become vitally important. Advances in technology mean new forms of connectedness, from fast and independent communication with local political actors, to access to knowledge about movements and practices around the globe. The difference this has made for feminist engagement, from within and outside development institutions, is significant.

\section{The struggle for interpretive power}

The "story" of gender in development in donor agencies takes its form from the constant repackaging of ideas that produces a regular reassertion of key axioms in the guise of different cloak-words, from "poverty reduction" and "empowerment" to "rights", "exclusion" and "citizenship". In the process, some aspects of gender agendas are privileged and others discarded, as dissonant meanings are pushed out of the frame. Depending on this frame, identical projects have distinctively different prospects; harnessing the discursive power of certain terms may provide levers for opening up policy space, but also limits what is possible as these terms also define domains of discourse that have their own boundaries.

A number of articles examine the discursive aspects of feminist narratives of development directly. The "stylised facts", stories and images that have been used in the making of "Gender and Development" have done a great deal. They have facilitated the dedication of resources, the production of policy space, the creation of a cadre of professionals and a body of organisations of various kinds whose work is to deal with issues of gender. In these contexts, gender myths are an outcome of negotiation and contestation - as Maxine Molyneux put it at the workshop, they are 'part of a struggle for interpretive power'. Rosalind Eyben's analysis of how particular images and ideas about women were put to use in a series of booklets produced by the UK Government's Overseas Development Administration (now Department for International Development, DFID), reveals how this 'struggle for interpretive power' works in the 
context of a large aid bureaucracy. Reflecting on this experience at the workshop, Rosalind highlights not only the strategic uses to which myths were put, but also the tactical moves made by gender advocates within the organisation to win spaces and push the boundaries of what was acceptable:

Some myths we believed in at the time, some were included because they went down well with management, some were instrumental, some are embarrassing, some we couldn't put in earlier because we didn't have the power ...

Others highlight the importance of myths in getting resources to women and the potential hazards of abandoning them in favour of representing what is a much more complex reality. As Sylvia Chant suggests, the pervasive representation of femaleheaded households as the poorest of the poor achieves a sleight of mind that permits a conflation of women per se with poverty, the implications of which have been so effectively explored by Cecile Jackson (1996). It becomes barely possible to imagine conditions under which female-headed households thrive, let alone those in which women would actively choose to free themselves from partnerships with men. And yet, Sylvia observes, bringing women and poverty into the same discursive frame has worked, to some extent, to enable some women to gain better access to resources.

The articles also contain much less benign examples, pointing to cautionary tales about instrumentalism and the ambivalent benefits of alignment with discursive framings of mainstream development. There are many dangers when the struggle for interpretive power is lost and myth making and stereotyping become the ways in which gendered power relations are reproduced. This is a point made forcefully by Rekha Pappu in her analysis of the discourse of education in the Indian context. Education may not be the unmitigated good that it is often portrayed to be; indeed, without examination of the content and hierarchical implications of educational processes, education itself may both reinforce stereotypes and limit opportunities. Everjoice Win demonstrates how the discursive position as perpetually poor, powerless and pregnant works to place African women as illiterate victims of national systems of resource distribution and disadvantage, putting them in such abject positions that only development can rescue them. It represents its objects as so lacking in the resources that underpin agency, and in such political and economic deficit, that they will never be able to get into a position on their own from which they can make claims. Powerlessness described in this way by outsiders simply serves to reinforce it.

Participants were very aware that the struggle over meaning occurs and has occurred in a discursive landscape that has constantly been changing. Some of the most contested discursive terrain in today's development discourse is around notions of "empowerment". As associations with collective action and more radical transformative agendas are sloughed away to make the notion palatable to the mainstream, "empowerment" has become about individual women having a little more money. The myth of female autonomy is one that many of us would like to see as untroubled. Yet Srilatha Batliwala and Deepa Dhanraj show just how troubling the convergence can be between certain ways of thinking and doing gender and pervasive neo-liberal policy choices that centre on enabling women to have their own money. They take the example of self-help groups in India, favoured for their association with "empowerment", and suggest that they may not only have deepened the immiseration of poorer women, but that they have also deflected their energies away from other forms of engagement, not least the political.

A further lesson from the articles and the workshop is that the struggle for interpretive power is not simply a struggle against and struggle for, it is also a struggle within. By this we mean that the myths, stories and fables we ourselves make are part of the discursive work we do to make sense of the world. Discourses are not just tactical, but are powerful forms of interpretation for ourselves as well as others. They enable us to act. If we discard the notion of interests in favour of a language of rights and citizenship, or displace the language of conflict with the language of trade-offs, is this only, or even primarily, an opportunistic response? Do we spot a potential discursive space that will unlock resources or get us to the table with the powerful and adopt it mainly for these reasons? We think not. We adopt different languages about how we explain the routes to gender justice and equality to ourselves because we have learnt from experience. What certain gender myths, feminist fables and stylised facts can, and cannot, do has become much 
clearer through the mixed successes and failures of feminisms in the last 20 years. Inevitably, the history of that period is also a history of debates, disputes and dialogues within feminism and between feminists. We shift and change our discourse and analysis in response to those histories.

\section{International feminism in troubling times}

GAD originated in a particular era of feminist thinking that was embedded in the politics of the time. Revisiting feminist agendas and their relationship with development calls not only for taking stock of what has happened with gender in development, but also for a broader view that takes in the much-changed global setting. New global economic relations underpin several of the articles. In Brazil, Cecilia Sardenberg indicates how 'a perverse combination of the processes of globalisation, production restructuring and the large-scale advancement of neo-liberalism' are widening the social and economic inequalities between women, and between men and women, as well as between the races, classes and generations. Amina Mama's article describes the difficult conditions in which feminists work on gender at the under-resourced universities of Africa. ${ }^{6}$ And the worsening everyday conditions of women's lives is a main theme in Ruth Pearson's commentary, which places today's GAD debates about the relation between empowerment and work for women within a historical context of theorising this relation and in an empirical context in which 'being exploited by capital is the fate of virtually all women in today's global economy'. Arguing that increases in wages will not on their own make women either less poor or more powerful, Ruth urges minimum income, labour regulation and proper social policy as key feminist expectations from states, which should resource the collective provision of services and recognise women's reproductive responsibilities.

Running through the commentaries in the last section and throughout the workshop is a renewed concern with the triple locations of the international, the local state and local feminisms. "Development" and development actors are but one part of this wide canvas. What feminism has come to mean in different locales is diverse, and situated in particular histories, particular struggles. Such differences are potentially very divisive and they are and have been a source of ongoing tension between feminists working at international levels in a range of politically located organisations, and between feminists located internationally, regionally and nationally.

As the workshop proceeded, it became clear that repositioning gender in development was not simply a matter of thinking anew what gender is, and of finding new ways to engage with development institutions. More urgent was the need to explore a feminist response to the darkening international political climate of the new millennium that could both respect and bridge difference. Deniz Kandiyoti's reflections on her work in post-Taliban Afghanistan illustrates just how narrow the political space for international feminist solidarity work might be and the need for highly nuanced and contextual responses to support national and local women activists. The geopolitical context she identifies is that of the new politics of armed democratisation and regime change within in-aptly named failed states - those that are war torn, lack governance and whose political economies are based on illegal trade in drugs, arms or high value commodities. Along with Islah Jad and Anne Marie Goetz, she questions the effects of the good governance, democratisation and women's rights "trinity" at the core of international development policy for the new US-dominated regimes. Emphasising that prospects for Afghani women depend on the outcomes at the national level of struggles over constitutional and citizenship rights, she suggests that women activists may end up the losers, because of 'a growing gap between discourses in transnational feminist networks, politics at the national level and the ways in which gender relations which are embedded in complex layers of historical and cultural determination' are actually being played out in the everyday.

The urgent task for gender and development feminists is to find an 'appropriate politics of solidarity' (Kandiyoti) when 'conservative forces are building alliances and have more effective strategies' (Molyneux). Echoing themes raised in Srilatha Batliwala and Deepa Dhanraj's article, Anne Marie Goetz and Maxine Molyneux reflect on the troubling state of feminism in the context of a resurgence of ideologies, meta-narratives and the exercise of power from the right. They affirm a stronger sense of the value of feminisms in today's political climate, suggesting that excessive soul-searching about the value of feminism as ideology, vision and form of organising may be misplacing vital energy. Anne Marie reminds us that many feminisms have had 'a 
moral vision beyond gender inequality' and implies the need to renew 'imagined social alternatives' from within autonomous feminist organising.

Maxine and Anne Marie foreground the state as the main credible site to launch long-term projects of social justice, a theme in a large number of articles in the workshop. Maitrayee Mukhopadhyay and Nandinee Bandopadhyay's articles give detailed case studies of feminist engagement with the local state. Maitrayee describes how the gender unit of a donor organisation worked closely with women's civil society organisations that were challenging dominant conceptions of both women's rights and entitlements. The coalition of Indian sex workers described by Nandinee has succeeded in undermining deeply entrenched stereotypes about both sex work and trafficking in novel and challenging ways. An increasingly important dimension is the scope for solidarity with and between autonomous women's movements that increasing communication and connectivity, especially through the internet, can provide. ${ }^{7}$ But how and with what success organised women can make demands on the state will be very different for different local feminisms. A particularly important variable here is what scope for sovereign decisions is left after the effects of "democratisation" enforced by either arms or heavy aid dependency.

\section{Solidarity across difference}

Feminist engagement with development has required the embrace of simplifications, in order to make strategic alliances and some inroads in the intensely political arena of policy-making. This in turn requires vigilance and struggle to avoid women being represented as cardboard victims or heroines, and to keep discourses open enough to capture nuances, ambiguities and complexities in real women's lives and choices. As Prudence WoodfordBerger argues, the kinds of alliances that we now need are those based around a politics of identification rather than the, often unhelpful, oppositional stereotypes that have been the stuff of so much gender myth-making. Alliances are always made at some costs, because they are made with those who share some, but not all, political goals; and while all the workshop participants agreed on the need for such alliances, it was infinitely more difficult to agree on the point at which compromise becomes defeat.

When do "some costs" become costs that are just too great? Maxine Molyneux's article points to several commentaries that suggest that the transformative agenda has been 'neutralised not to say excised', not because of technicification or bureaucratisation, but from 'a theoretical position that sees integration into existing states and institutions as, in itself, an abandonment of the broader, "critical" and at least implicitly revolutionary goals of much second wave feminism' (Molyneux, this IDS Bulletin). This view was not much in evidence at the workshop, where admittedly participants were weighted towards a predominantly UK-influenced history that centres on a number of key institutions. Yet the relationship between GAD and feminism remained a contested one. Positions varied from Ruth Pearson's reflection that 'it might be time to disinter feminism from GAD', to Marjorie Mbilinyi's suggestion that this entails talking about re-politicising feminism, and Cecilia Sardenberg's observation that "doing gender" had come to represent something safe, something different to "doing feminism" and that "if we are talking feminism, we are talking politics'. If participants differed in their ownership of gender and development, they re-affirmed feminist ownership of gender and the importance of continuing to engage with policy, replying 'No' to a question Ruth Pearson posed: 'Do we then disown this wayward daughter we created, because we don't like her company?'

This engagement is, of course, always more than the struggle for interpretive power. The form and content of policy must also be kept open and this too involves debate, dialogue and dispute. This was particularly evident in the workshop assessment of the growth of rights-based approaches from feminist perspectives that saw this development very differently. Dzodzi Tsikata's commentary records her profound misgivings with the adoption of rights language by UN agencies and international donors and lenders. She remarks on two coincidences: first, that the requirement by international agents that Southern governments guarantee more rights for their citizens coincides with their promotion of economic policies which restrict access to basic services; and second, that these requirements are being made at the same time as US and UK governments have denied their responsibility to international law to pursue the socalled "war on terror" and are eroding their own citizens' civil and political rights and some women's rights. Without understating the importance of rights and rights talk for feminists, she suggests that 
there is little reason to believe that top-down rights approaches will be any more likely to deliver gender justice than previous top-down approaches, especially given the great difficulty the majority of women have in accessing any forms of justice at all.

Other contributors noted that rights-based approaches at the moment frequently serve the powerful and were concerned at the origin of rights talk in Western individualism. For yet others, however, rights-based approaches represent a considerable advance. As Maitrayee argues, talking about rights privileges women's identities as citizens, rather than simply as mothers, wives and daughters (Lister 2003; Meer with Sever 2003). The language of rights lays claim to public space for women. After all, as Maxine reminds us, women's movements in a number of continents have used the instruments of human rights as a basis for their struggles, countering a thin utilitarian version of rights' with a wider ethic of socioeconomic justice to provide a new normative and analytic framework for fighting discrimination and injustice. For Everjoice Win, rights talk requires a critical shift that "would see us moving beyond our favourite African woman, to strategic engagements with those other women who not only need support but who can be strategic allies and leaders in development. But of course this means the power

\section{Notes}

* We incurred many debts in producing the workshop and this IDS Bulletin. Julia Brown worked tirelessly to organise the workshop and Jenny Edwards made a huge contribution to the smooth running of the entire project, from initial contacts with workshop participants to the coordination of this IDS Bulletin. We are enormously grateful to them both for their skills, attention to detail, hard work and commitment, which we have called on in full measure. We would also like to thank Alison Norwood for her forbearance and patience to us as Editors. Many thanks also to Dorte Thorsen and Emma Jones and a team of IDS and Sussex postgraduate students for their help at the workshop and to our colleagues at IDS, especially at BRIDGE and in the Department of Anthropology at the University of Sussex, for their support.

1. The workshop on 'Gender Myths and Feminist Fables: Repositioning Gender in Development Policy and Practice' was organised jointly by the Institute of Development Studies and the Department of Anthropology at the University of Sussex. It was funded by DFID, Sida and the Swedish Ministry of Foreign Affairs. We are very grateful to them for their support for the workshop and for the production of this IDS Bulletin. The views expressed in this introduction are those of the authors alone. relations between Northerners and African women also shifts dramatically' (Win, this IDS Bulletin).

For these strategic engagements, new forms of partnership are needed that are sensitive to the differences that have divided us and the dangers of the polarities "development" constructs. The workshop brought together women who had been active as feminist thinkers and actors in gender and development from a wide range of locations. These differences, which have been, and are, a fertile field for division and conflict, emerged in the workshop as debate and dissent. Reflecting on different perspectives on a troubled history gave us a growing sense of the possibility of working towards an appropriate politics of solidarity and working in ways that respect difference. For these we need, as Amina Mama argues, to foster the 'independent networks and intellectual strategies that enable us to continuously challenge and critique policies, but also to provide alternative visions and ideas for how to do it better' (this IDS Bulletin). It is through finding new ways of working with difference, expanding the possibilities for building appropriate forms of solidarity to create new alliances for influence and action that bridge old divides, that feminist engagement with development can begin to meet some of the formidable challenges that we all now face.

2. Georges Sorel argues: '... myths are not descriptions of things, but expressions of a determination to act ... A myth cannot be refuted since it is, at bottom, identical with the convictions of a group' (1941: 33).

3. Ferguson (1999) has used the term abjection to describe this positioning with respect to Africa and this certainly resonates meaningfully with the gender constructs under scrutiny.

4. A full list of articles presented at the workshop and of workshop participants can be found at the end of this IDS Bulletin. A separate special journal issue is planned containing a further selection of articles. Summaries of workshop articles are available at: www.siyanda.org (enter 'gender myths' as keywords into the search engine).

5. For elaboration of the issues of gender within PRSPs (Poverty Reduction Strategy Papers) and PAs (Poverty Assessments) see Lockwood and Whitehead (1999) and Whitehead (2003).

6. This is discussed in greater length in Mama (2004).

7. Amina Mama commented forcefully at the workshop on regional inequalities in internet access and the incorrect assumption that most African academics and activists now have good access. 


\section{References}

Ferguson, J., 1999, Expectations of Modernity: Myths and Meanings of Life on the Zambian Copperbelt, Berkeley: University of California Press

Goetz, A.M., 1997, Getting Institutions Right for Women in Development, London: Zed Books

Hirschmann, A., 1967, Development Projects Observed, Washington, D.C.: Brookings Institution

Jackson, C., 1996, 'Rescuing gender from the poverty trap', World Development, Vol 24 No 3: 489-504

Jackson, C. and Pearson, R. (eds), 1998, Feminist Visions of Development: Gender Analysis and Policy, London: Routledge

Kabeer, N., 2003, Gender Mainstreaming in Poverty Eradication and the Millennium Development Goals: A Handbook for Policy-Makers and Other Stakeholders, London: Commonwealth Secretariat and International Development Research Institute (IDRC)

Kabeer, N., 1994, Reversed Realities: Gender Hierarchies in Development Thought, London: Verso

Lister, R., 2003, Citizenship: Feminist Perspectives, Houndmills, Basingstoke: Palgrave Macmillan

Lockwood, M. and Whitehead, A., 1999, Gender in the World Bank's Poverty Assessments: Six Case Studies from Sub-Saharan Africa, Geneva: United Nations Research Institute for Social Development (UNRISD)
Macdonald, M., 2003, 'Gender equality and mainstreaming in the policy and practice of the UK Department for International Development (DFID): a briefing from the UK Gender and Development Network', London: UK Gender and Development Network

Mama, A., 2004, 'Critical capacities: facing the challenges of intellectual development in Africa', inaugural address Prince Claus Chair in Development and Equity, The Hague: Institute of Social Studies (ISS)

Meer, S. with Sever, C., 2003, 'Gender and citizenship: overview report', Gender and Citizenship Cutting Edge Pack, Brighton: BRIDGE, Institute of Development Studies

Miller, C. and Razavi, S. (eds), 1998, Missionaries and Mandarins: Feminist Engagement with Development Institutions, London: Intermediate Technology Publications in association with United Nations Research Institute for Social Development (UNRISD)

Rai, S., 2003, Mainstreaming Gender, Democratizing the State? Institutional Mechanisms for the Advancement of Women, Manchester: Manchester University Press

Sorel, G., 1941, Reflections on Violence, New York: Peter Smith

Whitehead, A., 2003, 'Failing women, sustaining poverty: gender in Poverty Reduction Strategy Papers', Report for the UK Gender and Development Network, London: Christian Aid 